\title{
Eastern and Western Romance in the Balkans - the Contrasting but Revealing Positions of the Danubian Romance Languages and Judezmo
}

\author{
Victor A. Friedman \\ Andrew W. Mellon Distinguished Service Professor Emeritus, Humanities \\ and Department of Linguistics, The University of Chicago, Chicago, Illinois, \\ USA, and Honorary Associate, Department of Languages and Linguistics, La \\ Trobe University, Melbourne, Australia \\ vfriedm@uchicago.edu \\ Brian D. Joseph \\ Distinguished University Professor, Department of Linguistics, and The \\ Kenneth E. Naylor Professor of South Slavic Linguistics, Department of \\ Slavic and East European Languages and Cultures, The Ohio State University, \\ Columbus, Ohio, USA \\ joseph.1@osu.edu
}

\begin{abstract}
The fate of two languages in the Balkans under conditions of language contact is discussed here. These languages, representing different branches of the Romance family, are the Ibero-Romance language Judezmo from the eastern branch and the South Danubian language Aromanian from the western branch. Both have been subject to intense contact with other languages in the Balkans but they show differential outcomes of this contact and thus differential degrees of involvement in the Balkan sprachbund. We document the similarities and differences in these outcomes, offer an explanation of their causes, and discuss the consequences they have for understanding the Balkan sprachbund.
\end{abstract}

\section{Keywords}

Aromanian - Judezmo - Balkan sprachbund - Balkanism 
The Balkans - the southeast European peninsula named for the mountain range running through the eastern part of that peninsula - are now, as they have been in the past, home to several languages of the Italic branch within Indo-European, including Latin in ancient times and various Romance languages more recently. While the similarities among these latter languages are interesting and useful for understanding the development of the Romance languages as a group, the differences they show offer especially important perspectives on the language contact situation in this part of the world. In what follows, we explore these differences and their import for understanding the Balkans. Various preliminaries about Romance languages and about Balkan language contact are needed to set the stage for this exploration; these are provided in Sections 2 and 3, after which we focus on two specific Romance languages in the region, Aromanian and Judezmo, also known as Judeo-Spanish or Ladino, and then present the contrasts in their development in Section 4 and discuss the consequences of these contrasts in Sections 5 and 7 , with a specific case-study of the developments with the infinitive in Section 6. ${ }^{1}$

Our basic thesis here is that a comparison of Aromanian and Judezmo is very revealing regarding the Balkan sprachbund in that Aromanian is very "Balkan" along various parameters to be argued for, while Judezmo is less so, much less so actually. Thus, this is a "tale of two languages" and pits eastern Romance versus western Romance in the Balkans. ${ }^{2}$

1 In using the name Judezmo, we follow Bunis (2018: 185-187), who gives a thorough discussion of almost all the names this language has been known by since its inception. (Victor A. Friedman can add that he has heard the term Spanyol in what is now North Macedonia). Here Bunis' (2018: 189) conclusion after a discussion of the various names, their origins and meanings is worth quoting: "Nevertheless, djudezmo still enjoys some popular use among native speakers and is the name preferred by many Jewish-language scholars - as a unique innovation arising within the speaker community; because of its designation of the language as a 'Jewish language', sharing terminological parallels with some other Jewish languages (e.g., Yiddish); and as a memorial to major Judezmo-speaking communities, such as those of Salonika, Bitola (Monastir), and Rhodes, many of whose everyday members called their language djudezmo until they were annihilated in the Holocaust."

2 Victor A. Friedman wishes to thank the John Simon Guggenheim Memorial Foundation and the Fulbright-Hays Program whose fellowships enabled him to conduct research among the last remaining speakers of Judezmo as well as many Aromanian speakers in what is now North Macedonia in 2008-2009. The material adduced here for Aromanian and Judezmo is all from published sources as noted in the list of references, and thus mostly treats 2oth century Judezmo, but the text as a whole is also informed by Victor A. Friedman's fieldwork, with the support of the aforementioned fellowships, and by Brian D. Joseph's interviews in the early 198 os with some diaspora Judezmo speakers originally from Thessaloniki, there being very 


\section{Romance Languages in the Balkans}

We first contextualize the mention here of a pair of Romance languages in the Balkans. There are actually a number of Romance languages in this part of the world, and five of them are of interest here, spanning, as indicated in Section 1, the two major branches of Romance: Eastern Romance and Western Romance. We exclude from consideration here both Dalmatian, once spoken along the coast of the Adriatic in what is now Croatia and on some of the Adriatic islands, as it is a poorly attested and now-extinct language (as of June 10, 1898 when the last user of the language, Tuone Udaina, died in an accident), and Italian, spoken still in those parts of Slovenia and Croatia that are adjacent to Italy.

Four eastern languages are relevant to our discussion, namely those that constitute the Balkan Romance branch within the east: the North Danubian Balkan Romance languages Romanian (see Maiden, 2021) and Istro-Romanian (see Loporcaro, Gardani and Giudici, 2021), and the South Danubian Balkan Romance languages Aromanian and Meglenoromanian. ${ }^{3}$ These languages are the outgrowth of Latin, first brought to the Balkans in the third century $\mathrm{AD}$, though it is a matter of some debate as to whether there is continuity in Romania with those Latin speakers. Of these, Aromanian is of particular interest here, for reasons that become clear in Section 3. One western language is at issue here, the Ibero-Romance language Judezmo, brought to the Balkans by Spanish-speaking Jews driven out of Iberia at the end of the 15th century.

Both Aromanian and Judezmo are spoken in various places in the Balkans, all of which were part of the Ottoman Empire. Aromanian is spoken in what is now Greece, North Macedonia, Albania, and southwestern Bulgaria - and, until recently, also what is now Kosovo - with diaspora communities in Serbia, Romania, and elsewhere. Judezmo, unlike Aromanian, is spoken both within and outside of the Balkans (especially North Africa, where it is also known as Haketia). In the Balkans, Judezmo was spoken in Ottoman towns, in what is now Greece, North Macedonia, Kosovo, Serbia, Montenegro, Bosnia-Hercegovina, the Dalmatian Coast, and Bulgaria; eventually, some Judezmo speakers migrated from Bosnia-Hercegovina and Bulgaria to Romania, settling mainly in Bucharest.

few speakers left in Thessaloniki now. Like all languages, Judezmo, where it is still spoken, continues to change, but the phenomena observed here are still part of the living language in at least some places, and represent the contact-induced changes that are the point of this paper.

3 Whether Moldovan constitutes a separate language within this branch distinct from Romanian is a question that is beyond the scope of the present contribution. See Dyer (1996; 1999), who notes that the Standard Moldovan has the same Wallachian dialect base as Standard Romanian. Since 2013, the official language of the Republic of Moldova has been Romanian. 
Our attention is largely on the Judezmo and Aromanian of Greece, but we make reference to the other locales as appropriate for our argumentation.

\section{$3 \quad$ Language Contact in the Balkans}

The Balkans have long been a locus of language contact, from ancient times to the present. The point of departure for a comparison of Aromanian and Judezmo is the well-known outcome of intense contact among speakers of different languages in the Balkans alluded to in Section 1, the so-called Balkan sprachbund, an artifact of both language geography and language contact. ${ }^{4}$ A sprachbund can be defined as a collection of geographically connected languages that through multilateral, multigenerational, mutual, multilingual contact over hundreds of years have come to share certain structural and lexical characteristics. For the Balkans, these characteristics are generally referred to as "Balkanisms". In the linguistic literature on the Balkans, Balkanisms are generally held to be structural features, elements of grammar, especially morpho-syntactic in nature, but the languages show convergence with regard to phonological features as well.

In addition to the structural side of Balkan sprachbund convergence, there is - as the definition given here indicates, and as noted by Trubetzkoy (1923;1930) - a lexical side as well, as suggested already by Miklosich (1861), a key figure in 19th century Balkanistics. In Friedman and Joseph $(2014 ; 2022)$, in a consideration of the lexical convergence of the sprachbund, we recognize a special set of conversationally based loanwords that arise under the sprachbund conditions adduced above, i.e., precisely the conditions that give rise to the structural convergence. We develop the notion of the "ERIC loan", an acronym standing for loans that are "Essentially Rooted In Conversation". ${ }^{5}$ ER IC loans depend on and thus demonstrate - intimate and sustained (both socially and temporally) everyday conversational interactions among speakers, and they include such items as the following:

$$
\begin{aligned}
& \text { Kinship terms } \\
& \text { - Numerals } \\
& \text { - Pronouns } \\
& \text { - Adpositions }
\end{aligned}
$$

4 Following Friedman and Joseph (2022), we treat this term as an assimilated loanword from German into English.

5 The acronym also pays homage to the late Eric Hamp, a mentor to both of us, the dean of Balkan linguistics and a Balkanist par excellence. 
- Negatives

- Complementizers

- Discourse elements (connectives, attitudinal expressives, interjections, gestures)

- Vocatives

- Onomatopoeia

- Reduplication (especially of an expressive nature)

- Shared phraseology

These categories of ERIC loans in some instances involve closed class items and grammatical forms not usually thought of as (easily) borrowable, and yet they are borrowed throughout the Balkans, attesting to an intense and sustained kind of language contact in the region leading to the sprachbund.

As the brief characterization of Aromanian and Judezmo in Section 1 shows, not all of the languages that are located geographically in the Balkans show Balkanisms and ERIC loans to the same degree; rather, just a subset of these languages show a considerable number of these features. Accordingly, it is convenient to recognize a distinction between "languages of/in the Balkans" - a geographical notion - and "Balkan languages", those languages of/in the Balkans that show contact-induced convergent features, and thus participate in the contact that created the Balkan sprachbund. Of the languages of interest here, Aromanian, Meglenoromanian, and, Romanian are "Balkan languages" in this categorization, as well as of course, "languages of the Balkans", and Istro-Romanian is just a language of the Balkans; Judezmo is, of course, a language of the Balkans, but its status as a "Balkan language", in the sense adopted here, is less well defined, as the discussion below indicates. That is, returning to our basic claim, a comparison of Aromanian and Judezmo shows Aromanian to be very much a Balkan language, and Judezmo somewhat less so, and this difference is revealing regarding the Balkan sprachbund.

\section{4 Comparing Aromanian and Judezmo}

How does one substantiate a claim as to the degree of "Balkan-ness" of the languages in question, operating with a distinction between "language of the Balkans" and "Balkan language"? Since the latter is a language that shows "Balkanisms", a necessary first step is to assemble a set of Balkanisms and see where a given language falls with respect to that set. We caution, however, against any inference that there is a purely quantitative answer to the question of relative "Balkan-ness", since the judgment as to whether a particular 
feature is found in a language is most often not a matter of simply seeing if some speaker or other accepts that feature; rather, a more nuanced concern for dialectology and history is needed. For instance, in Albanian, Aromanian, and Macedonian, there is a construction with an impersonal nonactive verb form in Albanian - in Aromanian and Macedonian with a functionally equivalent active verb form with a reflexive marker - and a pronominal dative of interest that gives the meaning 'I feel like vERB-ing', e.g., 'I feel like eating' in (2). ${ }^{6}$

$\begin{array}{lllll}\text { a. } & \text { më } & & \text { hahet } & \text { (Albanian) } \\ & \text { me.DAT } & & \text { eat.3SG.NACT } & \\ \text { b. } & \text { nji-si } & & \text { mãcã } & \text { (Aromanian) } \\ & \text { me.DAT-3.REFL } & & \text { eat.3SG.PRs' } & \\ \text { c. } & \text { mi } & \text { se } & \text { jade } & \text { (Macedonian) } \\ & \text { me.DAT } & \text { REFL } & \text { eats.3SG.PRs } & \end{array}$

For most varieties of Greek, including the standard language, such a construction is not possible, but it does occur in the Greek of the area in the north of Greece around Kastoria, an area where Greek speakers have been in contact with Albanian, Aromanian, and Macedonian speakers, as in (3).
(3) $m i$
trojiti
(Kastoria Greek)
me.ACC
eat.3SG.NACT

So, does Greek have that construction? In a very real sense, it does since some dialects of Greek show it, but at the same time, one could say it does not. That is, in general in Greek, this particular construction does not occur, but for some speakers of Greek, in particular those who have been in contact with a language that has that construction, it does occur. Thus there is a qualitative dimension to any determination of whether a given feature is found in a language.

In the remainder of this section, we present a listing of some of the more prominently discussed Balkanisms and an indication of where Aromanian and Judezmo stand with respect to them. Of particular concern for the discussion here are those features for which one or both of the languages show "yes" in the listing below; if both languages show "no", then there is no contribution to a measuring of the degree of "Balkan-ness". But a "yes" indicates the possibility of a Balkan contact-based explanation for the convergent element in the language in question. However, for many of these features, the answer is not a simple yes or no, but rather is "yes, but" or "no, but", where the "but" reveals

6 See Papadamou and Papanastassiou (2013), Papadamou (2019) on this construction in Kastoria Greek and its counterparts in other Balkan languages; it is discussed also in Friedman and Joseph (2018; 2022: Ch. 7). These works are the sources for the data in (2) and (3). 
the qualitative side to the evaluation of the occurrence of a particular feature. Moreover, as becomes clear below, in some instances, a "no" is actually a partial "yes" (as with the "feel-like" construction in (2) and (3)), so that qualitative comments are essential. Admittedly, this list lends itself to a purely quantitative, "scorecard"-like, interpretation of what it means to be more or less "Balkan", but the qualitative commentary that is provided is what we consider to be most important as it demonstrates that one cannot assess the presence or absence of a feature in a superficial manner. ${ }^{7}$ With such caveats in mind, we turn now to the features and the relevant qualitative discussion, presenting them in the lettered items $(\mathrm{A})$ through $(\mathrm{Q})$ with numbered examples where appropriate, and relevant discussion. ${ }^{8}$

(A) case reduction in the nominal system

$\begin{array}{ll}\text { Aromanian } & \text { YES (but ...) } \\ \text { Judezmo } & \text { YEs (but ...) }\end{array}$

For Aromanian, it must be noted that case distinctions are still present in the language, as it differentiates between a nominative-accusative form and a genitive-dative form for the definite article and certain pronouns. The specific genitive-dative merger is characteristic of many other Balkan languages and may in itself be a Balkanism. Nonetheless, Aromanian, like the rest of Balkan Romance, is anomalous among Romance languages in showing case distinctions at all, even if reduced from what is found in Latin. As for Judezmo, the lack of case distinctions is a total lack, but it is characteristic of Western Romance more generally, found in Portuguese, French, and Catalan, among other languages; thus this particular feature of Judezmo was brought to the Balkans from Iberia, so that overall, the apparent similarity between Aromanian and Judezmo as far as case reduction is concerned is of no consequence from a Balkanological and language-contact perspective.

(B) enclitic definite article

$\begin{array}{ll}\text { Aromanian } & \text { YES } \\ \text { Judezmo } & \text { NO (but ...) }\end{array}$

7 See Friedman and Joseph (2022: Sections 1.2.3, 3.3, 3.4.2.2) for a critique of the purely quantitative approach to the Balkan sprachbund. See also Friedman and Joseph (2017).

8 Given the space limitations, we cannot go into great detail here, both in the description of the feature in question and in the qualitative commentary; see Friedman and Joseph (2022) for a fuller discussion of all the Balkan features mentioned here. 
In this case, the absence from Judezmo of the Balkan feature of a definite article that is enclitic within the noun phrase, as in Aromanian om-lu bun 'the good man' (literally 'man-the good'), must be viewed against the backdrop that the language came from Iberia to the Balkans with a well-developed article system. ${ }^{9}$ Thus one might well wonder why it would show change in the direction of the Balkan system at all. This absence might also be connected with the chronology of the entry of Judezmo into the Balkans, a point taken up in Section 7 below.

(C) analytic comparatives

$\begin{array}{ll}\text { Aromanian } & \text { YEs (but ...) } \\ \text { Judezmo } & \text { YEs (but ...) }\end{array}$

Both Aromanian and Judezmo show analytic marking of adjectival comparison, a feature found in all of the Balkan languages. However, this feature is found as well all across the Romance languages, so that the Judezmo analytic comparative most likely was brought from Iberia. Thus as with (A), this similarity has no significance as far as the Balkan sprachbund is concerned.

possessive use of dative enclitic pronouns
$\begin{array}{ll}\text { Aromanian } & \text { YES (but ...) } \\ \text { Judezmo } & \text { NO (but ...) }\end{array}$

The reason for the hedging here is that in addition to dative clitic pronouns used to mark possession, e.g., ínima-ñ 'heart-my', i.e., 'my heart' (Vrabie, 2ooo: $5^{2}$ ), Aromanian also has possessive adjectives, e.g., ínima a mea 'heart my', i.e., 'my heart' (ibid.; see also Papahagi, 1974, s.v. meu), and furthermore, like Spanish, Judezmo allows dative clitic pronouns that can signal a possessive sense, as in (4). ${ }^{10}$

9 In this regard, Judezmo is somewhat like Greek, which does not participate in the enclitic definite article feature in the way that Albanian, Balkan Romance, and Balkan Slavic do, most likely because Greek had a well-developed article system dating from the Classical Greek period. Balkan Slavic and Latin, by contrast, both came to the Balkans without a definite article, to judge from the evidence of Classical Latin and Old Church Slavonic, so that the development of an article, enclitic or otherwise, can be viewed in that context, and the shared fact of enclisis in Balkan Romance and Balkan Slavic is, at the least, suggestive of contact-induced convergence.

We thank an anonymous reviewer for bringing such examples to our attention. 


(4) le kemaron la kaza
him.DAT burned.3PL the house
'They burned his house'

While it may well be that the dative in (4) is a dative of interest or disadvantage, so that the possessive reading is more a matter of pragmatic inference than grammar per se, the more usual way of expressing possession in Judezmo is with possessive adjectives (e.g., mi 'my', tu 'your', su 'his/her'), like Spanish (as the texts in Crews (1935) clearly show). Moreover, the Aromanian datives attach to the possessed noun, as in other Balkan languages, whereas the Judezmo instances like (4) are verbal adjuncts, even if they can be construed as signaling nominal possession. Thus while there is some basis for saying that the languages agree on this feature, the situation is not clear-cut, and they do disagree on details regarding this means of expression for possession, with Aromanian siding with the Balkan pattern.

(E) the formation of a future tense based on a reduced, often invariant, form of the verb 'want'

$\begin{array}{ll}\text { Aromanian } & \text { YEs (but ...) } \\ \text { Judezmo } & \text { No (but ...) }\end{array}$

This feature actually presents a number of interesting issues pertaining to how to determine the degree of agreement between the languages. The future tense in Judezmo, as in other Romance languages, is based on an inflected form of the verb 'have', a formation found in Vulgar Latin. ${ }^{11}$ Interestingly, there are Balkan languages with a 'have'-based future, including Romanian, where it is an inheritance from Vulgar Latin, and Geg Albanian, where it possibly represents a calque from the Latin or from Slavic; moreover, the Balkan Slavic languages (Bulgarian and Macedonian) show a 'have'-based future when the verb is negated. ${ }^{12}$ As for Aromanian, while its future is based on 'want', there are Aromanian dialects in close contact with Macedonian that use 'have' in negated futures, a formation calqued on what occurs in Macedonian. Thus while there is agreement between Aromanian and Judezmo regarding 'have' in future formations, that agreement appears to be greater only if one counts

11 As an anonymous reviewer has reminded us, contemporary Judezmo quite frequently uses a periphrastic future with 'go' as an auxiliary rather than a synthetic future of the sort described here.

12 When the verb ima 'have' is not negated, it can still be used to refer to the future in Balkan Slavic, but with a sense of obligation or threat. 
the Aromanian dialects that have converged with Balkan Slavic regarding the negated future, and in general, Judezmo appears to show a structure parallel to that found in some other Balkan languages. In the final analysis, however, since the Judezmo future represents an inheritance from Vulgar Latin, it is harder to take any parallelism between it and other Balkan languages regarding the basis of the future as definitively a Balkan contact effect. Thus although there is disagreement with regard to the occurrence of a 'want'-based future, and there is a superficial convergence in the future tense regarding 'have'-based futures, that parallelism is only superficial, as the commentary shows, and is of no Balkanological significance, as it does not result from contact in the Balkans.

(F) pluperfect with 'have' (sometimes in absence of a perfect)

$\begin{array}{ll}\text { Aromanian } & \text { YES (but ...) } \\ \text { Judezmo } & \text { YES (but ...) }\end{array}$

Both languages here show a periphrastic pluperfect formed with the verb 'have' as an auxiliary, together with a past participle. However, such a construction reflects a late Latin formation and is found all across the Romance languages, even if there has been a semantic shift from perfect meaning to that of a simple past in some of them (e.g., French and Italian and also some dialects of Romanian, but not in Aromanian). Thus, as with (C) above, the parallelism in structure is a matter of shared Romance inheritance from Latin and the similarity between the languages on this feature is not Balkanologically significant.

reduction/replacement of infinitive ${ }^{13}$
Aromanian
Judezmo

The facts here are that Aromanian, like Albanian, Bulgarian, Greek, Macedonian, and Romani, as well as other Balkan Romance languages, shows the absence of an infinitive, a grammatical category and form that once existed in the language, to judge from the evidence of Latin and the rest of the (non-Balkan) Romance languages. In place of an infinitive, Aromanian uses fully finite verbs (i.e., those marked for person and number of their subject) introduced by modal marker $s(i)$ or an indicative complementizer că. Judezmo, by contrast, preserves the Latin, and the Ibero-Romance, infinitive (as shown by the many instances in the texts found in Crews (1935) and in the examples in Quintana Rodríguez (2006: 163-169)), so that the infinitive-less Aromanian

13 See also Section 6 for more on the infinitive in Judezmo. 
differs significantly from the infinitive-rich Judezmo. Nonetheless, some uses of the subjunctive in Judezmo, e.g., in modal questions such as 'When might we come to get you?', mirror Balkan clauses with a bare subordinating marker (sM) unaccompanied by a controlling verb, as in (5a), a type which does not occur in either Modern Spanish or North African Judezmo, cf. (5b).

$\begin{array}{lllll}\text { (5a) kwando } & k e & \text { te } & \text { vengamoz a tom-ar? (Balkan Judezmo) } \\ \text { when that you.ACC } & \text { come.1PL to take-INF }\end{array}$

versus:

(5b) Cuando quieres que vengamos a recog-er-te?(Modern Spanish) when want.2SG that come.1PL to take-INF-you

(literally: 'When do.you.want that we.come to take you?')

This distributional fact in itself suggests Balkan contact influence, and this suggestion becomes all the more compelling when parallel constructions in contact languages, such as Greek in (5c), are adduced.

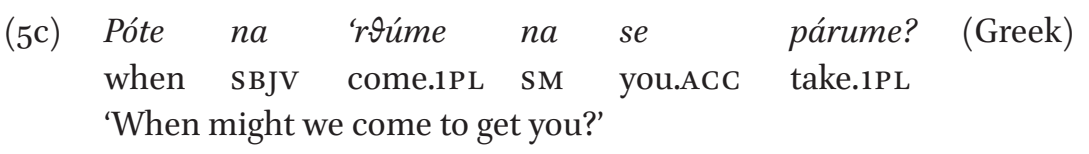

In this respect, the finite formation that replaces infinitives in most of the Balkan languages takes on a usage in Judezmo parallel to that found throughout the Balkans, thus aligning Judezmo with the results of the loss of the infinitive in a language like Aromanian.

(H) prepositional marking of personal

direct objects

Aromanian

Judezmo

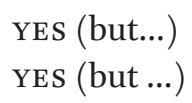

There is a parallelism here, to be sure, but it turns out to be irrelevant in and of itself, for two reasons. First, the prepositions involved are different, with $a$ occurring in Judezmo but pi/pe in Aromanian, and, second, this prepositional usage is found here and there across Romance. It is found, for instance, in some Italian dialects and Sardinian, and, importantly, in Iberian Spanish, where the preposition in question is also $a$. Thus the occurrence of this feature in Judezmo 
and Aromanian would seem to continue a Romance construction, and in any case, for Judezmo, it is just continuing an Iberian Spanish construction.

(I) doubling (cross-indexing) of an object by a weak ("clitic") pronoun $\begin{array}{ll}\text { Aromanian } & \text { YES } \\ \text { Judezmo } & \text { YES (but ...) }\end{array}$

In this case, despite the structural parallelism, it is not at all clear that there is anything significant here as far as Balkan language contact is concerned, because this same construction occurs in Iberian Spanish; thus most likely, its occurrence in Judezmo reflects the language's Ibero-Romance origins and was brought to Balkans from Spain when Judezmo speakers took refuge in this region. However, as with the infinitive vs. subjunctive, there are Judezmo reduplications that are not typical of the Ibero-Romance type, given in (6a) and (7a) with Macedonian parallels in (6b) and (7b), all from Kolonomos (1995).

(6a) Il palu tuertu la lumeri lu indireche the stick crooked the fire it.ACC straightens

(6b) kriv stap ogn-ot go ispravuva crooked stick fire-DEF it.ACC straightens 'A crooked staff is straightened in the fire' (Kolonomos, 1995: 267)

(7a) Al hamor kwandu mas l' aroges mas to.DEF donkey how.much more it.ACC beg.2SG more alvante las urezhe raise.3SG the ears

(7b) Magare-to kolku poveke go moliš donkey-DEF how.much more it.ACC beg.2SG poveke gi diga ushi-te more them.ACC raises.3SG ears-DEF 'The more you beg the donkey, the more it raises its ears.'

(J) evidentiality Aromanian YEs (but ...) Judezmo Yes (but ...) 
Evidentiality broadly speaking refers to the grammatical encoding of marking for source of information in a given statement or the speaker's attitude toward that source. Evidentiality as a broad category includes the admirative complex, where a form expressing attitude toward source can also express surprise or disbelief (see Friedman, 2012). It is found in several Balkan languages, in particular Bulgarian, Macedonian, Albanian, as well as Turkish; the standard view is that Turkish provided a model for the emergence of grammatical evidentiality in these other languages (see Friedman, 2018). Interestingly, this feature occurs in a limited way in Aromanian, in that it is found just in one dialect, that of Bela di Supră Frasheriote Aromanian in Macedonia (Friedman, 1994); it is however, a development resulting from contact with Albanian, so that it is a relatively recent, contact-induced development. As for Judezmo, some speakers of the language of Istanbul use the pluperfect as a calque on the Turkish (unwitnessed) past in -miş, as in this example from Varol (2001).

Kuando estavan $\quad$ en l' Amérika les
when were.3PL $\quad$ in the America them.DAT
aviya entra-do $\quad$ ladrón
had.3SG enter-PST.PTCP thief
'When they were in America [i.e., absent], a thief (apparently) broke
into [Turkish girmiş] their house.'

The distribution of evidentiality in both Aromanian and Judezmo therefore demonstrates that each language is responding to local conditions of contact, much as is the case with Greek and the impersonal construction discussed above and illustrated in (2) and (3). Moreover, the restricted nature of the occurrence of the feature in these languages raises the same questions as seen in the Greek case about how to judge a given language vis-à-vis a given feature. Still, the facts here show that each language in part, to a certain extent, has moved in the direction of a Balkan structural type, so that with regard to this feature, the agreement between the languages is of some Balkanological interest.

(K) occurrence of a stressed mid-central vowel

$\begin{array}{ll}\text { Aromanian } & \text { YES } \\ \text { Judezmo } & \text { NO }\end{array}$

Here the languages disagree, with no caveats, and Judezmo shows the absence of a feature that Aromanian exhibits. However, it is of some relevance with regard to the status of Judezmo vis-à-vis the sprachbund only insofar as 
stressed schwa is considered a Balkan feature, which, as Hamp (1977) argues, it is not (cf. also Friedman and Joseph, 2022: Ch.5).

(L) "clear" vowel system (i.e., with no "overlay" features such as nasalization or length)

Aromanian YES

Judezmo No

Crews (1935) reports that for the Judezmo of Thessaloniki, sequences of $a / o+$ $n$ develop into "nasalized vowels in final position". Thus Judezmo deviates in this respect from what is found in other Balkan languages in having developed a nasal vowel, but then Geg Albanian has a rich system of nasals and long vowels, some Macedonian dialects have developed phonemic length, and length is also to be found in Lab and Çam, at the southern end of Albanian. As with (14), then, the presence of nasality in Judezmo and thus the absence of this "clear-vowel" feature from the language differentiates it from Aromanian, but not necessarily in a way that is Balkanologically significant (Hamp, 1977).

(M) "Hissing" / "hushing" opposition (roughly: apico-dental / alveo-palatal) in fricatives and affricates, i.e., $\mathrm{s} / \int$, ts $/ \mathrm{t} \int$, and so also for voiced counterparts:

Aromanian

Judezmo

$$
\text { YES (e.g., with [dz] vs. Romanian [dz]) }
$$

YES

With its [c], [dz], and [dz], Judezmo diverges from other Spanish dialects; [t $\left.\int\right]$, by contrast, occurs in many Spanish dialects besides Judezmo. In this way, then, both Judezmo and Aromanian show movement in the direction of a Balkan phonological norm. The agreement seen in these two languages therefore gives each one a Balkan phonological system as far as affricates are concerned. This is thus a development of potential significance from a Balkanological standpoint.

(N) Presence of at least two members of the set [ts t6 t $]$ ]

$\begin{array}{ll}\text { Aromanian } & \text { YES } \\ \text { Judezmo } & \text { YES }\end{array}$

As with the previous feature, the unqualified affirmative in each language can be taken to be Balkanologically important, showing the languages to both have a Balkan aspect to their respective phonological systems. 
(O) $\quad \mathrm{NT}>\mathrm{ND}(\mathrm{N}=$ nasal; $\mathrm{T}=$ voiceless stop; $\mathrm{D}=$ voiced stop $)$

$\begin{array}{ll}\text { Aromanian } & \text { YES } \\ \text { Judezmo } & \text { NO }\end{array}$

Here the languages disagree with no relevant qualification needed aside from the fact that the progressive voicing is localized within the Balkans; this feature is therefore a way in which Judezmo does not show a local Balkan phonology.

$$
\begin{array}{ll}
\varnothing>\mathrm{a} / \# \_\mathrm{C} & \\
\text { Aromanian } & \text { YES } \\
\text { Judezmo } & \text { NO (but...) }
\end{array}
$$

The caveat for Judezmo here is due to the fact that even though forms like amañana 'tomorrow' (cf. Castillian Spanish mañana) do occur sporadically in the language, similar forms occur in Portuguese (cf. amanha 'tomorrow'); this suggests that the prothetic $a$ - may be a Spanish or Portuguese dialectism brought to the Balkans and not a feature that arose on Balkan soil.

(Q) ERIC loans

$\begin{array}{ll}\text { Aromanian: } & \text { YES } \\ \text { Judezmo: } & \text { YES }\end{array}$

Both languages show a number of the conversationally based ERIC loans, though Aromanian includes a number of grammatical loans as well; a sampling of the relevant evidence is given here.

(8a) widespread Balkan discourse items are found in both: bre 'hey you' (unceremonious term of address); ayde 'c'mon!', na 'here (it is); here ya go!', aman 'oh my; mercy!', but only one evaluative or connective type occurs in Judezmo (zatén 'indeed' (< Turkish zaten), whereas these are far more plentiful in Aromanian, e.g., ağeaba 'is it so?' (< Turkish acaba), belchi 'perhaps' (< Turkish belki), ghio(i)a 'as if' (< Turkish gûya), sanchi 'as if' (< Turkish sanki)

(8b) a widespread Balkan taboo expression occurs in Judezmo: asiktar 'scram; go to hell' (from Turkish, actually stronger in force)

(8c) bound morphology from Turkish occurs in Judezmo -lik e.g., hanukalik 'Chanukah present' (< Turkish qualitative or concrete -lik)

(8d) in Aromanian, adpositions are borrowed, one even (karşi 'opposite' (< Turkish postposition $k a r s ̧ i)$ ) borrowed as a postposition; also, there is borrowing of pronouns (especially $-m$ 'my' (< Greek $m u)$ ). 
The agreement between Aromanian and Judezmo in this feature thus seems to be Balkanologically significant, and suggests a degree of integration into Balkan speech communities on the part of both languages. The grammatical loans in Aromanian, as in (8d), however, mark it as being more thoroughly Balkan in regard to this feature than is Judezmo.

\section{5 \\ Assessment}

Taking stock of all the features surveyed in Section 4, we see that some features are inconclusive as to the degree of "Balkan-ness" of Judezmo, whereas others show what might be termed a trend in the direction of the language being fully "Balkan", especially in its phonology and lexicon, but also, as far as morphosyntax is concerned, in the way finite complementation is used, and, perhaps object reduplication. Taking them all together, the picture is pretty clearly one in which Aromanian is deeply embedded in the Balkan sprachbund, both structurally and lexically, whereas Judezmo is a peripheral member at best; Judezmo is lacking many features that have been identified as relevant for the Balkan sprachbund, whereas Aromanian has several Balkan features that Judezmo does not show and there are none that are found in Judezmo to the exclusion of Aromanian.

It must be noted, though, that the inconclusive features, in particular those that most likely were brought from Iberia to the Balkans by Judezmo speakers, are not completely irrelevant. That is, features such as analytic marking of adjectival comparative degree (cf. (C)), prepositional marking of direct objects (cf. (H)), and clitic object doubling (cf. (I)), even if not due to contact in the Balkans on the part of Judezmo speakers, nonetheless would make Judezmo appear to be structurally rather like its Balkan neighbors in typological terms, even if contact-induced processes of convergence were not at work. That is, whatever their origin, these features contribute to the overall "look" of the language as far as Balkan structural characteristics are concerned. Moreover, the even if these features, as part of the Romance inheritance of the language, predated the entry of Judezmo into the Balkans, their continued presence could have been enhanced by contact with Balkan languages possessing them; that is to say, contact effects are not simply a matter of gain or loss of a given feature.

\section{6} On Causes of Differences - the Infinitive as a Case-Study

Shifting our focus somewhat, we offer a case-study into causation by way of examining why Judezmo shows only a subset of common Balkan characteristics. 
To do so, we turn to developments with the infinitive, thus expanding the discussion of feature $(G)$ above.

First, it is a fact that at least into the last decades of the 2oth century, Judezmo of Thessaloniki had an infinitive with uses that parallel Castillian Spanish (Joseph, 1983: 252ff., and see the discussion and references in $(G)$ above in Section 4). This is so even though many, if not most, speakers, in the 2oth century at least, were bilingual in infinitive-less Standard Greek and in constant contact with monolingual speakers of Standard Greek, which was, after all, essentially the Greek of Orthodox Christian speakers. Moreover, the fact that the early Spanish starting point for Judezmo had an infinitive is no guarantee that the infinitive would persist, for there are Romance languages that have lost their infinitive through contact with a language with a restricted infinitive; in particular, Italian dialects in southern Italy show reduced infinitival usage as opposed to the rest of Italian (Rohlfs, 1958; see also Ledgeway, Schifano and Silvestri, 2021), possibly due to sustained contact with Southern Italy Greek (and/or Albanian (Arbëresh), see also Breu, 2021), which has an infinitive to a greater degree than the rest of Greek but much less so than a "standard" Romance language. It is thus a matter of some interest as to why Judezmo has retained its infinitive so robustly.

As a suggested answer, we note that Jewish languages in general are said to be conservative possibly due to the general segregation of Jewish communities. Such segregation would have created situations in which Jewish speakers would have less access to linguistic innovations found in the usage of coterritorial non-Jewish speakers or less willingness to adopt them. The Judeo-Greek of 16th century Constantinople offers a possible case in point, as it has archaic infinitival usage paralleling that of New Testament Greek (Joseph, 2000; 2019), and different from what occurs in the contemporary Greek of non-Jews. By contrast, Aromanian has been in the center of the Balkans, with at least the males in contact with Greek, Albanian, and/or Macedonian for centuries longer; Récatas (1934) describes gender-based village bilingualism in Aromanian communities in the Pindus region of Greece, for instance.

The foregoing has been a comparative exercise contrasting Aromanian and Judezmo, in which the fate of two different Romance languages was examined in their Balkan context. If we can generalize from this study, it seems that there are three lessons to draw. 
First, chronology matters - having substantially more time for speakers to interact can make a difference to outcomes; the fact of less contact time for Judezmo than for Aromanian must surely have played a role in the extent to which possible structural changes in Judezmo under conditions of contact with various Balkan languages could have taken hold and been generalized throughout the language.

Second, structure matters - what a language starts with in terms of structural properties can make a difference for outcomes; the preservation of the Judezmo article as an element that could occur in first position in a noun phrase would seem to be a case in point.

Finally, and perhaps most importantly, social circumstances matter - being restricted in the nature of the interactions with speakers of other languages can make a difference to outcomes; the developments with the infinitive in Judezmo would be an example of this factor, as Judezmo speakers had more restricted access to other Balkan languages than Aromanian speakers did, and that seems to have made a difference with regard to the infinitive.

These three points converge in a way, for in their totality they offer the opportunity for interaction between speakers of different languages in a mutual, multi-lateral, multi-generational, multi-lingual mode what Friedman and Joseph (2022: Ch.8) refer to as the "four-M" model for language contact and sprachbund formation.

\section{Abbreviations for categories absent from the Leipzig Glossing Rules}

NACT non-active

SM subordinating marker

\section{References}

Breu, Walter. 2021. Italo-Albanian: Balkan inheritance and Romance influence. Journal of Language Contact 14(1): 147-183.

Bunis, David. 2018. Judezmo (Ladino/Judeo-Spanish): A historical and sociolinguistic portrait. In Benjamin Hary and Sarah Bunin Benor (eds.), Languages in Jewish Communities, Past and Present, 185-238. Berlin: De Gruyter Mouton.

Crews, Cynthia M. 1935. Recherches sur le judéo-espagnol dans les pays balkaniques. Paris: E. Droz. 
Dyer, Donald (ed.). 1996. Studies in Moldovan: The History, Culture, Language and Contemporary Politics of the People of Moldova. Boulder: East European Monographs / New York: Distributed by Columbia University Press.

Dyer, Donald. 1999. The Romanian Dialect of Moldova: A Study in Language and Politics. Lewiston: Edwin Mellen Press.

Friedman, Victor A. 1994. Surprise! Surprise! Arumanian has had an admirative! Indiana Slavic Studies 7: 79-89.

Friedman, Victor A. 2012. Perhaps mirativity is phlogiston, but admirativity is perfect: On Balkan evidential strategies. Linguistic Typology 16(3): 505-527.

Friedman, Victor A. 2018. Where do evidentials come from? In Alexandra Y. Aikhenvald (ed.), The Oxford Handbook of Evidentiality, 124-147. Oxford: Oxford University Press.

Friedman, Victor A. and Brian D. Joseph. 2014. Lessons from Judezmo about the Balkan Sprachbund and contact linguistics. International Journal of the Sociology of Language 226: 3-23.

Friedman, Victor A. and Brian D. Joseph. 2017. Reassessing Sprachbunds: A view from the Balkans. In Raymond Hickey (ed.), Cambridge Handbook of Areal Linguistics, 55-87. Cambridge: Cambridge University Press.

Friedman, Victor A. and Brian D. Joseph. 2018. Non-nominative and depersonalized subjects in the Balkans: Areality vs. genealogy. In Jóhanna Barðdal, Na'ama Pat-El and Stephen Mark Carey (eds.), Non-Canonically Case-Marked Subjects. The Reykjavík-Eyjafjallajökull Papers, 23-53. Amsterdam:John Benjamins.

Friedman, Victor A. and Brian D. Joseph. 2022. The Balkan Languages. Cambridge: Cambridge University Press.

Hamp, Eric P. 1977. On some questions of areal linguistics. In Ken Whistler et al. (eds.), Proceedings of the 3rd Annual Meeting of the Berkeley Linguistics Society, 279-282. Berkeley: Berkeley Linguistics Society.

Joseph, Brian D. 1983. The Synchrony and Diachrony of the Balkan Infinitive: A Study in Areal, General, and Historical Linguistics. Cambridge: Cambridge University Press.

Joseph, Brian D. 200o. Processes of Spread for Syntactic Constructions in the Balkans. In Christos Tzitzilis and Christos Symeonidis (eds.), Balkanlinguistik: Synchronie und Diachronie, 139-15o. Thessaloniki: Aristotle University of Thessaloniki.

Joseph, Brian D. 2019. Can there be language continuity in language contact? In Edit Doron, Malka Rappaport Hovav, Yael Reshef, and Moshe Taube (eds.), Linguistic Contact, Continuity and Change in the Genesis of Modern Hebrew, 257-285. Amsterdam: John Benjamins.

Kolonomos, Žamila (ed.). 1995. Sefardski odglasi. Skopje: Ǵurǵa.

Ledgeway, Adam, Norma Schifano, and Giuseppina Silvestri. 2021. The negative imperative in Southern Calabria. Spirito greco, materia romanza again? Journal of Language Contact 14(1): 184-219. 
Loporcaro, Michele, Francesco Gardani, and Alberto Giudici. 2021. Contact-induced complexification in the gender system of Istro-Romanian. Journal of Language Contact 14(1): 72-126.

Maiden, Martin. 2021. Establishing contact. Slavonic influence on Romanian morphology. Journal of Language Contact 14(1): 24-52.

Miklosich, Franz. 1861. Die slavischen Elemente im Rumunischen. Vienna: Kaiserlichekönigliche Hof- und Staatsdruckerei.

Papadamou, Eleni. 2019. Northern Greek dialects of Kastoria as language varieties at the core of Balkan Sprachbund. In G. Papanastassiou et al. (eds.), Studies in Greek Linguistics 39. Proceedings of the Annual Meeting of the Department of Linguistics, School of Philology, Faculty of Philosophy, Aristotle University of Thessaloniki April 19-21, 2018, 793-801. Thessaloniki: Department of Linguistics, Aristotle University.

Papadamou, Eleni and George Papanastassiou. 2013. The position of the Northern Greek dialects of Kastoria among the Modern Greek dialects. In Mark Janse, Brian D. Joseph, Angela Ralli, and Metin Bagriacik (eds.), MGDLT5. Proceedings of the $5^{\text {th }}$ International Conference on Modern Greek Dialects and Linguistic Theory (Ghent, Belgium, September 20-22, 2012), 389-400. Patras: University of Patras. https:// pasithee.library.upatras.gr/mgdlt/article/view/2605/2842.

Papahagi, Tache. 1974. Dicționarul dialectului aromân. Bucharest: Editura Academiei Republicii Socialiste România.

Quintana Rodríguez, Aldina. 20o6. Geografía lingüística del Judeoespañol. Estudio sincrónico y diacrónico. Bern: Peter Lang.

Récetas, B. 1934. L'état actuel du bilinguisme chez les macédo-roumains du Pinde et le role de la femme dans le langage. Paris: Librarie Droz.

Rohlfs, Gerhard. 1958. La perdita dell'infinitivo nelle lingue balcaniche. Omagiu lui Iorgu Iordan cu prilejul împlinirii a 70 de ani, 733-744. Bucharest: Academiei Republicii Populare Romîne.

Trubetzkoy, Nikolai S. 1923. Vavilonskaja bašnja i smešenie jazykov. Evrazijskij vremennik 3: 107-124.

Trubetzkoy, Nikolai S. 193o. Proposition 16. In Cornelis de Boer, Jacobus van Ginneken and Anton G. van Hamel (eds.), Actes du Premier Congrès International des Linguistes à La Haye, du 10-15 Avril 1928, 17-18. Leiden: A.W. Sijthoff.

Varol, Marie-Christine. 2001. Calques morphosyntaxiques du turc en judéo-espagnol: Mécanismes et limites. In Anaïd Donabédian (ed.), Langues de diaspora, langues en contact, special issue of Faits de langues 18: 85-99.

Vrabie, Emil. 2000. An English-Aromanian (Macedo-Romanian) dictionary: With two introductory sketches on Aromanian. University, Miss: Romance Monographs. 